\title{
Integrating Green Tourism and Bioenergy for Sustainable Rural Development: the Example of the Hemp Cluster in Sumy Region in Ukraine
}

\author{
Hanna Shevchenko ${ }^{1}$, \\ ${ }^{1}$ Institute of Market Problems and Economic-Ecological Research of the National Academy of Science \\ of Ukraine, Department of Economic Management of Natural Resources, Frantsuz'ky Blvd, 29, 65044 \\ Odesa, Ukraine
}

\begin{abstract}
Institutional support for the transition to sustainability, agricultural traditions, as well as land use regimes create favorable conditions for the development of bioenergy, in particular in the field of biomass related activities, in rural territories of Ukraine. The purpose of the study is to analyze the factors and substantiate the relationship between green tourism and bioenergy in the context of expanding areas of sustainable rural development, on the example of agro-tourism hemp cluster in Sumy region in Ukraine. The research methodology: the theoretical-game approaches to balance the interests of stakeholders in rural development are applied in the paper, namely in the context of renewable energy, waste management and recreational and tourism activities. SWOT analysis was also applied with rationale of strategic directions of agro-tourism clusters development in the conditions of transitive economy. The rationale of proposals for improving the institutional support of sustainable rural development at the regional level allows to form a basis for increasing the level of investment attractiveness of projects such as agro-tourism hemp cluster. Besides, recommendations for the integration of green tourism and bioenergy are focused on the advanced development of rural areas with the involvement of other sectors of the economy, in particular, waste management.
\end{abstract}

\section{Introduction}

For transition economies, in conditions of insufficient financial resources and at the same time efforts to accelerate market transformations, it is advisable to use all possible organizational innovations at both territorial and sectoral levels. It is not only about the economic vector of development, in particular such industries as agriculture or energy, but also about such complex areas of socio-economic and environmental activities as green tourism.

Institutional support for the transition to sustainability [1, 2], agricultural traditions, as well as land use regimes create favorable conditions for the development of bioenergy in

\footnotetext{
* Corresponding author: hannashevchenko@gmail.com
} 
rural territories of Ukraine. A comprehensive approach to the use of agricultural land [3] in the context of their optimal diversification actualizes the search for intersectoral cooperation in the field of biomass related activities.

"The main sources of biomass in Ukraine are waste and agricultural residues.., and in the long run - energy crops grown specifically for this purpose"; as of today, $80 \%$ of renewable energy in Ukraine is biomass [4]. The potential for bioenergy development is presented in table 1 .

Table 1. Bioenergy potential of Ukraine.

\begin{tabular}{|l|l|}
\hline \multicolumn{1}{|c|}{ Type of biomass } & \multicolumn{1}{c|}{ Potential volume } \\
\hline Straw (cereals, rapeseed) & 10.86 million tons \\
\hline Waste (stems, rods, husks, pulp) & 29.655 million tons \\
\hline Wood biomass & 3.78 million tons \\
\hline Biogas (agro-industrial waste, landfills, wastewater) & 1.234 billion $\mathrm{m}^{3}$ \\
\hline Energy crops (willow, poplar, miscanthus, corn) & $13.32{\text { billion } \mathrm{m}^{3}}^{2}$ \\
\hline
\end{tabular}

Source: expert assessment of the Ukraine Bioenergy Association [5]

Hemp as a biomass needs further study, not only in terms of energy, but also in terms of waste management and agritourism. Technological aspects of hemp production have been developed in the papers [6,7]. The source [8] summarizes research on agritourism. The paper [9] analyzes renewable energy as a factor within the sustainable tourism development, the paper [10] identifies renewable energy and tourism as symbiotic socioeconomic sectors. The source [11] develops the widespread use of bioenergy to grow the national economy, with the "local context, empowerment of local governments and encouragement of both public and private initiatives". The papers [12-14] explore sustainable, eco, and green tourism. Innovations in the field of sustainable tourism are considered in [15], in particular, which are aimed at reducing carbon emissions and ultimately contribute to the fight against climate change.

At the same time, the complex interrelationships between the above-mentioned industries require further research.

The purpose of the study is to analyze the factors and substantiate the relationship between green tourism and bioenergy in the context of expanding areas of sustainable rural development, on the example of agro-tourism hemp cluster in Sumy region in Ukraine.

\section{Methodology}

The theoretical-game approaches (games against nature $[16,17]$ and mechanism design [18-20]) to balance the interests of stakeholders in rural development are applied in the paper, namely in the context of renewable energy, waste management and recreational and tourism activities (Fig. 1).

The formalization of the balance of interests for actors interested in the hemp development on the basis of the theoretical-game approach application is as follows:

$$
H_{i}\left(s^{*}\right) \geq H_{i}\left(s_{i}, s_{-i}^{*}\right)-\varepsilon
$$

where $H_{i}\left(s^{*}\right)$ - the result of the $i$ actor of hemp relevant activity (energy, tourism, waste management) in the equilibrium situation $s^{*}$, that belongs to a set of strategies $S=\left(s_{1}, s_{2}, \ldots\right.$ $\left.s_{i}, \ldots, s_{n}\right)$; depends on the strategies of all actors in the situation $s^{*} ; \varepsilon$ - conditional equilibrium parameter. 


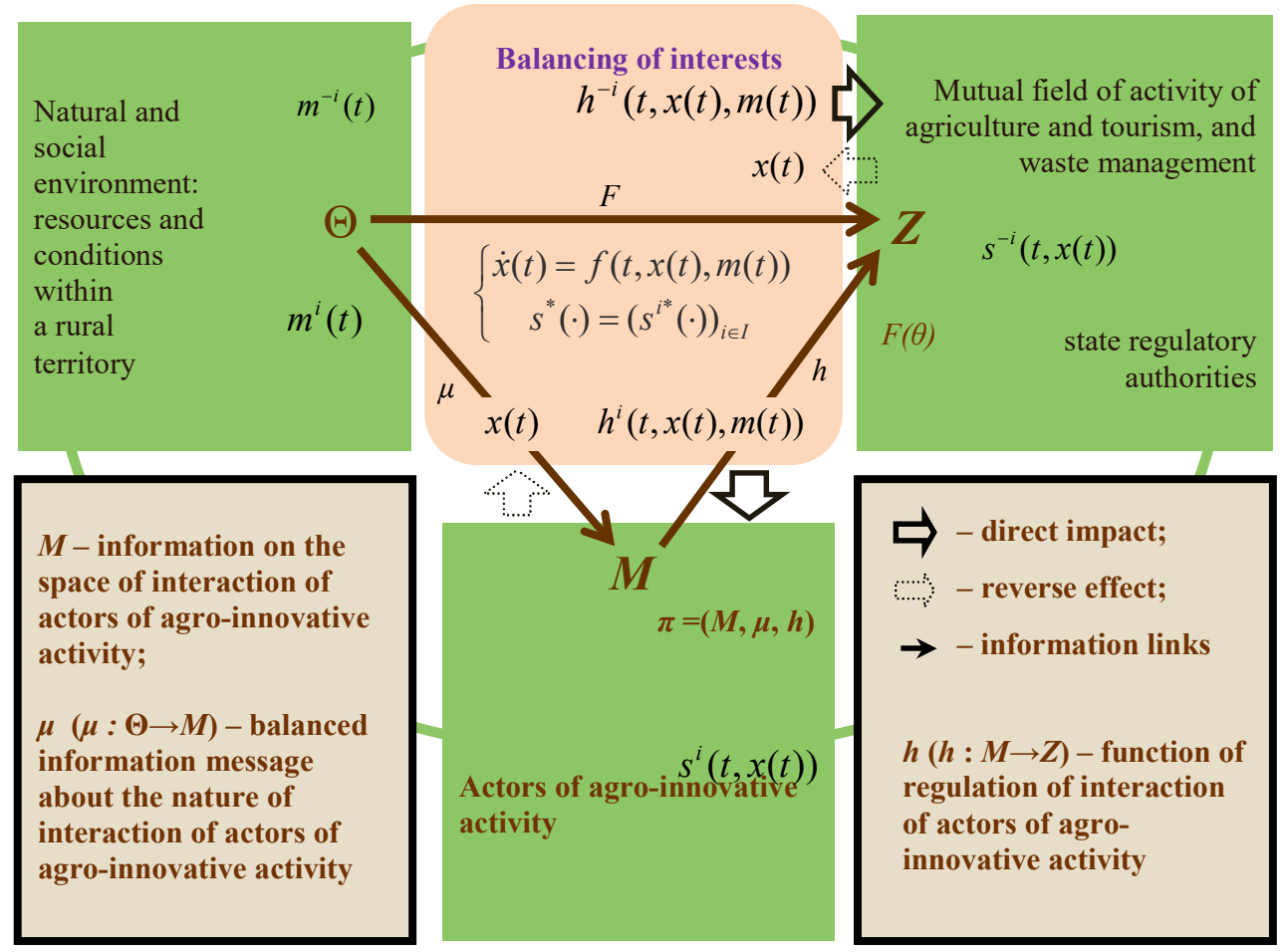

Fig. 1. A game-theoretical modeling of balancing the interests of actors within the agro-tourism cluster.

Source: Developed by the author based on $[19,20]$

The data in the study cover regional and sectoral [21, 22], as well as national [1, 23] levels. These data have an economic, social and environmental context, as well as a socioeconomic, economic-environmental and integrated context. The search for primary information, which is summarized in the secondary data, is also partially carried out during the study of relevant documentation of organizations.

SWOT analysis was also applied with rationale of strategic directions of agro-tourism clusters development in the conditions of transitive economy (the example of application is in [24]).

\section{Results}

For sustainable development of rural areas in transition economies, an innovative approach is needed, which provides a comprehensive combination of the advantages of different industries in their interaction and at the same time a return to the traditions of national agriculture, including hemp.

\subsection{Innovative policies to support rural development}

Starting in 2019, in Ukraine, despite the general socio-economic crisis in the country and as of 2020 the difficult situation associated with the COVID-19 pandemic, sustainable rural development continues. 
Table 2. Innovative projects for sustainable rural development in Ukraine.

\begin{tabular}{|c|c|c|c|}
\hline Project & Region & $\begin{array}{l}\mathrm{EU} \\
\text { finance }\end{array}$ & $\begin{array}{l}\text { Other } \\
\text { finance }\end{array}$ \\
\hline Restoration of irrigation of Kherson region $^{*}$ & Kherson & 4700 & 2300 \\
\hline $\begin{array}{l}\text { Incubator for starting a business in the field of } \\
\text { aquaculture }^{*}\end{array}$ & Mykolayiv & 5887 & 2974.4 \\
\hline Agro-industrial park in Shepetivka $^{*}$ & Khmelnytskyi & 21000 & - \\
\hline $\begin{array}{l}\text { Preservation of forest plantations and improvement of } \\
\text { ecological safety of rural areas }\end{array}$ & Kherson & 10308.4 & 1146 \\
\hline Production of eco-containers from biopolymers ${ }^{*}$ & Lviv & 7650 & 2150 \\
\hline $\begin{array}{l}\text { Interregional Innovation Center for Rural } \\
\text { Development }\end{array}$ & Ukraine & 12000.6 & 5182.56 \\
\hline $\begin{array}{l}\text { Creation of agro-tourist cluster "Slobozhanske } \\
\text { hemp""* }\end{array}$ & Sumy & 14123.031 & 6580 \\
\hline Glampings in protected areas $^{* * *}$ & Ukraine & 23986.04 & 4857.216 \\
\hline $\begin{array}{l}\text { Human capital development in the agro-organic } \\
\text { sector of the economy }\end{array}$ & Rivne & 3652.138 & 1218 \\
\hline $\begin{array}{l}\text { Development of tourism in sparsely populated rural } \\
\text { areas of Trostyanets UTC }\end{array}$ & Sumy & 5107.036 & 2745.954 \\
\hline $\begin{array}{l}\text { Slavutych - interregional cycling recreation for } \\
\text { health and leisure***** }\end{array}$ & Kyiv & 12322.66 & 2273.729 \\
\hline $\begin{array}{l}\text { Measures for waste sorting and utilization in nature } \\
\text { reserves of the Carpathians }\end{array}$ & $\begin{array}{l}\text { Trans- } \\
\text { carpathia }\end{array}$ & 4870.4 & 1050.6 \\
\hline $\begin{array}{l}\text { Creating a space for recreation in Zbarazh - overhaul } \\
\text { of the coastal zone of the lake }\end{array}$ & Ternopil & 9835.35 & 1735.98 \\
\hline $\begin{array}{l}\text { Introduction of "smart city" elements in rural } \\
\text { communities of Cherkasy region } * * * * *\end{array}$ & Cherkasy & 1248.761 & 1274.161 \\
\hline $\begin{array}{l}\text { Training of self-government representatives in } \\
\text { sustainable development of communities }{ }^{* * * * *}\end{array}$ & Kyiv & 1600 & 400 \\
\hline
\end{tabular}

Project groups: ${ }^{*}$ Innovative economy, ${ }^{* *}$ Rural development, ${ }^{* * *}$ Tourism development, ${ }^{* * * *}$ Human development, ${ }^{* * * * *}$ Support for the development of depressed areas, ${ }^{* * * * * *}$ Effective management of regional development

Source: compiled by the author on the basis [21]

The main advantage of the researched project is first of all that it is complex and relevant to almost all programs (Table 2).

Thus, according to the results of the competition [21], 56 projects were selected for 7 programs (innovative economy and investments, rural development, tourism development, human development, support for the development of depressed areas, effective management of regional development, all-Ukrainian solidarity) in the amount of over UAH 535 million. The sources of funding are the state budget, formed with EU funds. The topics of most projects are tourism (219) and innovative economy (137), as well as the development of depressed areas. (106). Project selection criteria: their complexity, socioeconomic effect for cities and regions, the applicant's ability to support the project in the future.

\subsection{Development of agro-tourist clusters in Ukraine}

The project revives traditions and diversifies the possibilities of agricultural production in Slobozhanshchyna, taking into account innovations in the cultivation of technical hemp, 
their processing, as well as the use of products of their processing in food and everyday life. To this end, the following is envisaged: comprehensive development of the hemp industry, with an increase in the scale of hemp cultivation and the provision of capacity for their processing; creation of a training center for the hemp development; development of rural and gastronomic tourism [22].

Extended project activities include the following main components:

- conducting trainings, "round tables", conferences;

- improvement of waste management processes according to the principles of circular economy;

- organization of festivals, museum and other tourist sites;

- informing the public about the project implementation.

An integrated approach to the formation of this cluster involves information and economic interaction of the three main activities relevant to innovative hemp, based on the design mechanism (Fig. 1). In turn, information interaction has been analyzed in the context of information asymmetry (1) and informational-innovation development (2); economic interaction is considered in terms of intersectoral processes (3) and the project approach (4), which requires the introduction of regulatory changes, namely:

1) promoting local openness and complete coverage of information on environmental and social activities, and on the other hand, significantly increasing control over the veracity of information data and the introduction of tougher fines for violators;

2) improving environmental monitoring with the use of innovations such as drone surveillance in the framework of public control, as well as strengthening the scientific component, including through citizen science;

3) strengthening coordination work in the field of industrial, science and technological parks, in the direction of strengthening intersectoral cooperation, in particular through its infrastructure;

4) a combination of participatory budgeting and public-private partnership practices in the field of innovative intersectoral activities.

In the energy context of cluster formation, the current issue in Ukraine is the "green" tariff, which purchases electricity produced on the basis of alternative energy sources, including bioenergy [25].

In Ukraine, the government guarantees timely current payment by the State Enterprise "Guaranteed Buyer" for electricity supplied to the United Energy System and repayment by the end of 2021 of debts to renewable energy producers, about 14 billion UAH. The government has also pledged to set and approve annual quotas to support green energy and ensure that auctions are held. The main condition of the memorandum is the refusal of the authorities from further attempts to change the "rules of the game" for the entire period of the "green" tariff - until 2030. The size of the "green" tariff for farm and home power plants will not change [26].

The basis for the introduction of special conditions of the "green" tariff for bioenergy is its environmental orientation and the promotion of rural development (more broadly - in table 3).

Despite the changes taking place in the socio-economic life of Ukraine and at the global level, investors are interested in renewable energy projects due to attractive conditions in the country. But high risks are an obstacle to investment. One of the risks is the choice of land for the location of the energy object [27]. To choose the right site for the construction of the power plant in Ukraine, it is necessary to analyze the following: natural and environment conditions, the possibility of connecting to the existing energy system (remoteness of the site from the grid, lack of energy infrastructure, especially transformer substations), land availability according to its purpose. In Ukraine, renewable energy facilities can be built on land for industry, transport, communications, and other purposes. 
Table 3. SWOT-analysis of strategic directions of agro-tourist cluster development in the transitive economy conditions.

\begin{tabular}{|c|c|c|c|}
\hline \multirow{2}{*}{\multicolumn{2}{|c|}{$\begin{array}{r}\text { External } \\
\text { environment }\end{array}$}} & Opportunities (O) & Threats (T) \\
\hline & & $\begin{array}{l}\text { Potential support from } \\
\text { international organizations, } \\
\text { in particular the UNWTO } \\
\text { Growing interest and } \\
\text { readiness of regional } \\
\text { organizations } \\
\text { Revival of interest and } \\
\text { research activities of pro- } \\
\text { environmental NGOs } \\
\text { The presence of business }\end{array}$ & $\begin{array}{l}\text { Lack of clear national } \\
\text { standards } \\
\text { Resource needs (finance, } \\
\text { technology and human } \\
\text { resources) } \\
\text { Inertia of cannabis } \\
\text { stereotypes } \\
\text { Complexity of bureaucratic } \\
\text { procedure (project } \\
\text { documentation, permits, etc.) }\end{array}$ \\
\hline & \multirow[b]{2}{*}{$\begin{array}{l}\text { Agro-industrial traditions } \\
\text { Land use mechanism } \\
\text { (compared to solar or wind } \\
\text { energy in rural areas in } \\
\text { Ukraine) } \\
\text { Complexity } \\
\text { Existing regional } \\
\text { development policy }\end{array}$} & Strategie & Strategies (ST) \\
\hline & & $\begin{array}{l}\text { Gradual introduction of the } \\
\text { cluster with simultaneous } \\
\text { broad development of } \\
\text { energy and tourism } \\
\text { Expanding the participation } \\
\text { of local governments } \\
\text { Special conditions of the } \\
\text { "green" tariff } \\
\text { Improving waste } \\
\text { management practices }\end{array}$ & $\begin{array}{l}\text { Mobilization of small and } \\
\text { medium-sized businesses } \\
\text { within the cluster through } \\
\text { diversified financial support } \\
\text { (both public and private } \\
\text { investment) } \\
\text { Introduction of training } \\
\text { programs } \\
\text { Strengthening institutional } \\
\text { support }\end{array}$ \\
\hline \multirow[b]{2}{*}{ 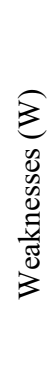 } & \multirow[b]{2}{*}{$\begin{array}{l}\text { Lack of experts } \\
\text { Slight development } \\
\text { experience } \\
\text { Lack of business motivation } \\
\text { due to distrust of the } \\
\text { authorities }\end{array}$} & Strategies (WO) & Strategies (WT) \\
\hline & & $\begin{array}{l}\text { Search for new opportunities } \\
\text { for circular development } \\
\begin{array}{l}\text { Consultations } \\
\text { international experts (e.g. } \\
\text { UNWTO) } \\
\text { Measures to increase trust in } \\
\text { government }\end{array}\end{array}$ & $\begin{array}{l}\text { Comprehensive assessment } \\
\text { of the feasibility and content } \\
\text { of project proposals } \\
\text { Ideologization and } \\
\text { propaganda } \\
\text { Involvement of all } \\
\text { stakeholders in projects }\end{array}$ \\
\hline
\end{tabular}

Source: Developed by the author

Ukrainian legislation allows changing the purpose of land, but there are significant difficulties with agricultural land (which has a special status). Each case is investigated separately. The issue of land ownership is the most controversial, so it is advisable to alternatively lease state or communal land; taking into account such factors as the availability of the decision-makers' authority within the transfer of land for use, as well as the correctness of the contract.

Given this, bioenergy has the least barriers to development within rural areas in Ukraine, and, as described above, is an important component for the creation of agrotourism clusters. 


\section{Conclusions}

The organizational-economic provisions developed in the paper substantiate the following:

- preconditions for creating rules of the game, namely through the following measures: promoting openness and complete coverage of relevant information, improving environmental monitoring, strengthening coordination in the field of innovational parks, combining the practices of participatory budgeting and public-private partnership;

- strategic directions of agro-tourist cluster development, in particular such as: the gradual introduction of the cluster with simultaneous broad development of energy and tourism, the mobilization of small and medium-sized businesses within the cluster through diversified financial support, the comprehensive assessment of the feasibility and content of project proposals etc.;

- the possibility of compensating the negative consequences of the green tariff policy with additional benefits of sustainability of rural territories through the integration of bioenergy and green tourism in Ukraine.

Also, the rationale of proposals for improving the institutional support of sustainable rural development at the regional level allows to form a basis for increasing the level of investment attractiveness of projects such as agro-tourism hemp cluster. Besides, recommendations for the integration of green tourism and bioenergy are focused on the advanced development of rural areas with the involvement of other sectors of the economy, in particular, waste management.

The paper contains the results of research conducted under the National Academy of Science of Ukraine's grant "Formation and use of natural-resource assets of the recreational and tourism sphere" (No. 0120U100159) and project "Inclusion of the experience economy in the nature management" (No. 0119U000229).

\section{References}

1. https://sustainabledevelopment.un.org/content/documents/26295VNR_2020_Ukraine_ Report.pdf [Accessed 24 May 2021]

2. https://ec.europa.eu/info/strategy/priorities-2019-2024/european-green-deal_en [Accessed 24 May 2021]

3. H. M. Shevchenko, V. M. Pakhomov, M. M. Petrushenko, Economic and legal issues of rural and recreational land use in Ukraine. Economic Annals-XXI. 156(1-2), 54-58. https://doi.org/10.21003/ea.V156-0012 (2016)

4. https://www.ua.undp.org/content/ukraine/uk/home/presscenter/pressreleases/2019/stud y-tour--undp-shared-best-bioenergy-practices-with-ukrainian-.html [Accessed 24 May 2021]

5. https://saee.gov.ua/node/586 [Accessed 24 May 2021]

6. P. Găgeanu, M. Olan, I. Găgeanu, A. Zaica, Theoretical considerations on the factors influencing the processing of hemp stalks. E3S Web Conf. 180, 03005. https://doi.org/10.1051/e3sconf/202018003005 (2020)

7. A. Păun, G. Stroescu, A. Zaica, R. Ciupercă, C. Bogdanof, E3S Web Conf. 180, 03026. https://doi.org/10.1051/e3sconf/2020180030026 (2020)

8. S. Rauniyar, M. K. Awasthi, S. Kapoor, A. K. Mishra, Tourism Recreation Research. 46, 1-19. https://doi.org/10.1080/02508281.2020.1753913 (2020)

9. M. Evanthie, Études Caribéennes. 11. https://doi.org/10.4000/etudescaribeennes.3487 (2008) 
10. H. Shevchenko, M. Petrushenko, A symbiosis between renewable energy and tourism: The case of Dnipro region in Ukraine. E3S Web Conf. 234, 00087. https://doi.org/10.1051/e3sconf/202123400087 (2021)

11. C. S. Goh, T. Aikawa, A. Ahl, et al, Rethinking sustainable bioenergy development in Japan: decentralized system supported by local forestry biomass. Sustainability Science. 15, 1461-1471. https://doi.org/10.1007/s11625-019-00734-4 (2020)

12. N. MacKenzie, M. J. Gannon, Exploring the antecedents of sustainable tourism development. Int. Journal of Contemporary Hospitality Management. 31(6), 24112427. https://doi.org/10.1108/IJCHM-05-2018-0384 (2019)

13. S.-Y. Pan, M. Gao, H. Kim, et al., Advances and challenges in sustainable tourism toward a green economy. Science of the Total Environment. 635, 452-469. https://doi.org/10.1016/j.scitotenv.2018.04.134 (2018)

14. N. D. Line, L. Hanks, L. Miao, Image matters: incentivizing green tourism behavior. Journal of Travel Research. 57(3), 296-309. https://doi.org/10.1177/0047287517697848 (2018)

15. H. Buijtendijk, J. Blom, J. Vermeer, R. van der Duim, Journal of Sustainable Tourism. 26(7), 1222-1240. https://doi.org/10.1080/09669582.2018.1433184 (2018)

16. M. Petrushenko, H. Shevchenko, B. Burkynskyi, N. Khumarova, A game-theoretical model for investment in inclusive recreation and wellness in Ukraine: the regional context. Investment Management and Financial Innovations. 16(4), 382-394. http://dx.doi.org/10.21511/imfi.16(4).2019.32 (2019)

17. J. Szép, F. Forgó, Games against nature. In: Introduction to the Theory of Games. Mathematics and Its Applications. 17. https://doi.org/10.1007/978-94-009-5193-8_21 (Springer, Dordrecht, 1985)

18. O. V. Prokopenko, M. M. Petrushenko, Marketing and Management of Innovations. 1, 254-266 (2013). https://mmi.fem.sumdu.edu.ua/journals/2013/1/254-266 [Accessed 24 May 2021]

19. L. Hurwicz, S. Reiter, Designing economic mechanisms (Cambridge University Press, New York, 2008)

20. M. M. Petrushenko, H. M. Shevchenko, Management of ecological-economical conflicts within the framework of the theory of optimal mechanisms for resource distribution. Actual Problems of Economics. 141(3), 186-192 (2013). https://ecoscience.net/downloads/ [Accessed 24 May 2021]

21. https://www.minregion.gov.ua/press/news/vyznacheno-peremozhcziv-konkursnogovidboru-proyektiv-regionalnogo-rozvytku/ [Accessed 24 May 2021]

22. https://sectoral.minregion.gov.ua/sectorals/128a0c70-1f94-11eb-ba4a-b356ee544eea [Accessed 24 May 2021]

23. http://www.ukrstat.gov.ua [Accessed 24 May 2021]

24. X. M. Zhang, Research on the development strategies of rural tourism in Suzhou based on SWOT analysis. Energy Procedia, 16(B), 1295-1299. https://doi.org/10.1016/j.egypro.2012.01.207 (2012)

25. https://zakon.rada.gov.ua/laws/show/555-15\#Text [Accessed 24 May 2021]

26. https:/www.ukrinform.ua/rubric-economy/3044409-mirovu-ugodu-sodo-zelenogotarifu-ukladeno-geruskriza-trivae.html [Accessed 24 May 2021]

27. https://getmarket.com.ua/ua/news/yak-pravil-no-obirati-zemel-ni-dilyanki-dlyabudivnictva-proektiv-vidnovlyuvanoyi-energetiki [Accessed 24 May 2021] 